\title{
Overview of blood-borne viral infections in hemodialysis patients: hepatitis $B$, hepatitis $C$, human immunodeficiency virus infections
}

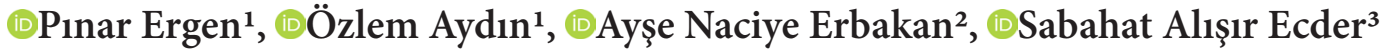 \\ ${ }^{1}$ İstanbul Medeniyet University, Göztepe Prof. Dr. Süleyman Yalçın City Hospital, Clinic of Infectious Diseases and Clinical Microbiology, İstanbul, Turkey \\ ${ }^{2}$ İstanbul Medeniyet University, Göztepe Prof. Dr. Süleyman Yalçın City Hospital, Department of Internal Medicine, İstanbul, Turkey \\ ${ }^{3}$ İstanbul Medeniyet University, Göztepe Prof. Dr. Süleyman Yalçın City Hospital, Clinic of Nephrology, İstanbul, Turkey
}

Cite this article as: Ergen P, Aydın Ö, Erbakan AN, Alışır Ecder S. Overview of blood-borne viral infections in hemodialysis patients: hepatitis B, hepatitis C, human immunodeficiency virus infections. J Health Sci Med 2022; 5(1): 195-200.

\begin{abstract}
Aim: This study aimed to examine the blood-borne viral infections such as hepatitis B, hepatitis $C$ and human immunodeficiency virus (HIV) and to determine the risk factors in hemodialysis patients.

Material and Method: The datas of patients who underwent hemodialysis in the hemodialysis unit of our hospital between March 1, 2020 and March 1, 2021 were reviewed retrospectively. Their sociodemographic characteristics, habits, underlying diseases and virological indicators related to hepatitis B, hepatitis C and HIV were obtained from patient files and hospital data processing system.

Results:A total of 96 patients were included in the study. Of them, $43.8 \%(n=42)$ were female and $56.2 \%(n=54)$ were male. Their mean age was $62.61 \pm 18.11$ years, ranging from 17 to 92 . The duration of dialysis was less than 3 months for $46.9 \%(n=45)$ of the patients, between 3 months and 3 years for $19.8 \%(n=19)$, and 3 years and above for $33.3 \%(n=32)$. Thirty patients (31.3\%) had diabetes mellitus. In addition, $1 \%(\mathrm{n}=1)$ of the patients had HBsAg positivity, $3.1 \%(\mathrm{n}=3)$ had anti-HCV positivity, $59.4 \%(n=57)$ had Anti- HBs positivity and $2.1 \%(n=2)$ had anti-HIV positivity. No statistically significant difference was found between the patients' HBsAg, anti-HCV and anti-HIV positivity according to gender, duration of dialysis, dialysis application site, alcohol use, surgical intervention and blood transfusion history ( $\mathrm{p}>0.05)$.

Conclusion: Hemodialysis patients may be at risk for hepatitis B, hepatitis C and HIV infection if infection control guidelines are not followed strictly. In addition to complying with these guidelines, both health workers and patients should be trained constantly, patients' virological indicators should be tested regularly and hepatitis B vaccine should be administered to hemodialysis patients without seroconversion.
\end{abstract}

Keywords: Hemodialysis, HBV, HCV, HIV, seroprevalance

\section{INTRODUCTION}

Hepatitis B virus (HBV), hepatitis C virus (HCV) and human immunodeficiency virus (HIV) are pathogens that can be transmitted by blood and blood products, causing significant public health issues across the world. Hemodialysis patients with end-stage renal disease are at risk due to transmission routes of these infections.

Turkey is a medium endemic region in terms of HBV infection with an estimated HBsAg positivity of $4 \%$ (1). Studies of hemodialysis patients have reported different rates of $\mathrm{HBsAg}$ positivity reaching at $8.7 \%$ (2). While anti-HCV positivity is estimated to be $1 \%$ in the population, studies report this rate up to $16 \%$

in hemodialysis patients $(3,4)$. According to the latest data, there are a total of 25,809 HIV-infected individuals across Turkey and HIV positivity is below $0.5 \%$ in hemodialysis patients $(5,6)$.

An evaluation of HBsAg, anti-HCV and anti-HIV positivity and Hepatitis $B$ vaccine responses of the patients followed up in the hemodialysis unit of our hospital will guide us in following up our patients, determining relevant risk factors and developingproper prevention strategies, and also contribute to the literature on the seroprevalence of hemodialysis patients in İstanbul, Turkey. 


\section{MATERIAL AND METHOD}

Patients followed in the hemodialysis unit of our hospital between March 1, 2020 and March 1, 2021 were included in the study. The study was approved by the Medeniyet University Göztepe Training and Research Hospital Ethics Committee (Date: 02.09.2020, Decision No: 2020/0551). The study was conducted in accordance with the Declaration of Helsinki rules. Their sociodemographic data, histories of blood transfusion and surgical intervention, vaccination status, alcohol and intravenous drug use, presence of fistula or catheter, duration of hemodialysis, and virological indicators (HBsAg, anti-HBs, anti-HBc total, anti-HCV, anti-HIV) were obtained retrospectively from patient files or hospital data processing system. Their HBsAg, anti-Delta, anti$\mathrm{HBs}$, anti-HBc total, anti-HCV and anti-HIV serology were tested using the enzyme linked immunosorbent assay (ELISA) method. Anti-HBs titer of $10 \mathrm{mIU} / \mathrm{mL}$ and above was accepted as protective antibody titer for hepatitis B. HBsAg, anti-HCV, anti-HIV positive patients were tested using HBV DNA, HCV RNA, HIV RNA test PCR (Polymerase Chain Reaction) method (Qiagen, Hilden, Germany) respectively.

\section{Statistical Analysis}

The Number Cruncher Statistical System (NCSS) program was used for statistical analysis. Descriptive statistical methods (mean, standard deviation, median, frequency, percentage, minimum, maximum) were used to evaluate the data. Shapiro-Wilk test and graphical examinations were used to test the conformity of quantitative data to normal distribution. MannWhitney $\mathrm{U}$ test was used for comparisons between two groups of quantitative variables without normal distribution. Pearson chi-square test, Fisher's exact test and Fisher-Freeman-Halton test were used to compare qualitative data. Statistical significance was accepted as $\mathrm{p}<0.05$.

\section{RESULTS}

A total of 96 patients were included in the study. Their mean age was $62.61 \pm 18.11$ years, ranging from 17 to 92 . Of the patients, $43.8 \%(n=42)$ were female, $56.2 \%(\mathrm{n}=54)$ were male, and $\% 77.6$ were married. The duration of dialysis was less than 3 months for $46.9 \%$ $(n=45)$ of the patients, between 3 months and 3 years for $19.8 \%(n=19)$, and 3 years and above for $33.3 \%$ $(\mathrm{n}=32)$. Thirty patients $(31.3 \%)$ had diabetes mellitus and five patients (5.2\%) had hypertension. In addition, there were history of malignancy in 9 patients $(9.3 \%)$ and polycystic kidney disease in 4 patients (4.2\%).
Of the patients, $1 \%(\mathrm{n}=1)$ had HBsAg positivity, 3.1\% $(\mathrm{n}=3)$ had anti-HCV positivity and $2.1 \%(\mathrm{n}=2)$ had anti-HIV positivity. The HBsAg positive patient had negative delta antibody. $\mathrm{HBsAg}$, Anti-HCV, AntiHIV positivities were all detected before starting the dialysis program. Anti-HBs positivity was observed in $59.4 \%(n=57)$ of the patients, and six (6) of them were naturally immunized. No isolated anti-HBc total positivity was observed. Anti-HBs values of six (6.3\%) patients who received Hepatitis B vaccine and developed protective antibody levels were found to be negative in the following examinations.

In addition, $46.9 \%(n=45)$ of the patients were on dialysis via fistula and $53.1 \%(\mathrm{n}=51)$ were on dialysis via catheter. Only $2.1 \%(n=2)$ of them were social drinkers, there were no patients with intravenous drug use. While $54.2 \%(n=52)$ had a history of blood transfusion, and $76 \%(\mathrm{n}=73)$ had a history of surgical intervention.

No statistically significant difference was found between the patients' $\mathrm{HBsAg}$, anti-HCV and anti-HIV positivity according to gender, duration of dialysis, dialysis application site, alcohol use, surgical intervention and blood transfusion history, and no additional risk factor was detected ( $p>0.05)$. Tables $\mathbf{1}, 2$ and 3 show the patients' HbsAg, anti-HCV and anti-HIV status and their demographic characteristics.

Table 1. Comparison of patients' HBsAg status according to their demographic characteristics

\begin{tabular}{|c|c|c|c|}
\hline & \multicolumn{2}{|c|}{ HBsAg } & \multirow{2}{*}{$\mathbf{p}$} \\
\hline & Negative $(n=95)$ & Positive $(n=1)$ & \\
\hline \multicolumn{4}{|l|}{ Age } \\
\hline Mean \pm Sd & $62.62 \pm 18.21$ & 62 & \\
\hline Median (Min-Max) & $64(17-92)$ & $62(62-62)$ & \\
\hline Gender & & & ${ }^{\mathrm{a}} 1.000$ \\
\hline Male & $53(55.8)$ & $1(100.0)$ & \\
\hline Female & $42(44.2)$ & $0(0)$ & \\
\hline Duration of dialysis & & & ${ }^{\mathrm{d}} 0.523$ \\
\hline$\leq 3$ months & $45(47.4)$ & $0(0)$ & \\
\hline 3 months - 3 years & $19(20.0)$ & $0(0)$ & \\
\hline$\geq 3$ years & $31(32.6)$ & $1(100.0)$ & \\
\hline Dialysis application site & & & ${ }^{\mathrm{a}} 0.469$ \\
\hline Fistula & $44(46.3)$ & $1(100.0)$ & \\
\hline Catheter & $51(53.7)$ & $0(0)$ & \\
\hline Alcohol use & $2(2.1)$ & $0(0)$ & ${ }^{\mathrm{a}} 1.000$ \\
\hline Surgical intervention & & & ${ }^{\mathrm{a}} 1.000$ \\
\hline No & $23(24.2)$ & $0(0)$ & \\
\hline Yes & $72(75.8)$ & $1(100.0)$ & \\
\hline Blood transfusion & & & ${ }^{\mathrm{a}} 0.458$ \\
\hline No & $43(45.3)$ & $1(100.0)$ & \\
\hline Yes & $52(54.7)$ & $0(0)$ & \\
\hline
\end{tabular}




\begin{tabular}{|c|c|c|c|}
\hline & \multicolumn{2}{|c|}{ Anti-HCV } & \multirow[b]{2}{*}{$\mathbf{p}$} \\
\hline & Negative ( $n=93)$ & Positive $(n=3)$ & \\
\hline \multicolumn{4}{|l|}{ Age } \\
\hline Mean \pm Sd & $62.89 \pm 18.23$ & $54.00 \pm 13.11$ & \\
\hline Median (Min-Max) & $64.5(17-92)$ & $56(40-66)$ & \\
\hline Gender & & & ${ }^{\mathrm{a}} 1.000$ \\
\hline Male & $52(55.9)$ & $2(66.7)$ & \\
\hline Female & $41(44.1)$ & $1(33.3)$ & \\
\hline Duration of dialysis & & & ${ }^{\mathrm{d}} 0.201$ \\
\hline$\leq 3$ months & $45(48.4)$ & $0(0)$ & \\
\hline 3 months -3 years & $18(19.4)$ & $1(33.3)$ & \\
\hline$\geq 3$ years & $30(32.3)$ & $2(66.7)$ & \\
\hline Dialysis application site & & & ${ }^{\mathrm{a}} 0.598$ \\
\hline Fistula & $43(46.2)$ & $2(66.7)$ & \\
\hline Catheter & $50(53.8)$ & $1(33.3)$ & \\
\hline Alcohol use & $43(46.2)$ & $2(66.7)$ & ${ }^{\mathrm{a}} 1.000$ \\
\hline Surgical intervention & & & ${ }^{\mathrm{a}} 1.000$ \\
\hline No & $43(46.2)$ & $2(66.7)$ & \\
\hline Yes & $50(53.8)$ & $1(33.3)$ & \\
\hline Blood transfusion & & & ${ }^{\mathrm{a}} 0.247$ \\
\hline No & $43(46.2)$ & $2(66.7)$ & \\
\hline Yes & $50(53.8)$ & $1(33.3)$ & \\
\hline
\end{tabular}

Table 3. Comparison of patients' anti-HIV status according to theirdemographic characteristics

\begin{tabular}{|c|c|c|c|}
\hline & \multicolumn{2}{|c|}{ Anti-HIV } & \multirow[b]{2}{*}{$\mathbf{p}$} \\
\hline & Negative $(n=94)$ & Positive $(n=2)$ & \\
\hline \multicolumn{4}{|c|}{ C } \\
\hline Mean \pm Sd & $62.80 \pm 18.22$ & $54.00 \pm 11.31$ & \\
\hline Median (Min-Max) & $64.5(17-92)$ & $54(46-62)$ & \\
\hline Gender & & & ${ }^{\mathrm{a}} 0.503$ \\
\hline Male & $52(55.3)$ & $2(100)$ & \\
\hline Female & $42(44.7)$ & $0(0)$ & \\
\hline Duration of dialysis & & & ${ }^{\mathrm{d}} 0.276$ \\
\hline$\leq 3$ months & $45(47.9)$ & $0(0)$ & \\
\hline 3 months - 3 years & $18(19.1)$ & $1(50)$ & \\
\hline$\geq 3$ years & $31(33)$ & $1(50)$ & \\
\hline Dialysis application site & & & ${ }^{\mathrm{a}} 0.217$ \\
\hline Fistula & $43(45.7)$ & $2(100)$ & \\
\hline Catheter & $51(54.3)$ & $0(0)$ & \\
\hline Alcohol use & $52(55.3)$ & $2(100)$ & ${ }^{\mathrm{a}} 1.000$ \\
\hline Surgical intervention & & & ${ }^{\mathrm{a}} 1.000$ \\
\hline No & $23(24.5)$ & $0(0)$ & \\
\hline Yes & $71(75.5)$ & $2(100)$ & \\
\hline Blood transfusion & & & ${ }^{\mathrm{a}} 1.000$ \\
\hline No & $43(45.7)$ & $1(50)$ & \\
\hline Yes & $51(54.3)$ & $1(50)$ & \\
\hline
\end{tabular}

The only HbsAg positive patient had been receiving hepatitis B treatment for ten years and his HBV DNA was undetectable. Two patients who were positive for antiHCV had negative HCV RNA and one of thembecame negative after antiviral treatment. The HCV RNA value of the other anti-HCV positive patient was $74.858 \mathrm{IU} /$ $\mathrm{mL}$. One of the anti-HIV positive patients had received
HIV treatment for two years and the other for nine years. Both patients had undetectable HIV RNA levels.

There was a statistically significant relationship between anti-HBs positivity and duration of dialysis $(\mathrm{p}=0.001$; $\mathrm{p}<0.01$ ). The rate of being negative for anti-HBs was higher in the patients with dialysis duration of 3 months or less, and the rate of being positive for anti-HBs was higher in those with dialysis duration between 3 months and 3 years and those with dialysis duration of 3 years and above. The rate of being positive for anti-HBs was statistically significantly higher in the patients with fistula than in those with catheter $(\mathrm{p}=0.001 ; \mathrm{p}<0.01)$. In addition, anti-HBs positivity was statistically significantly higher in the patients who underwent surgery than in those who did not $(\mathrm{p}=0.001 ; \mathrm{p}<0.01)$.

Laboratory characteristics of the study patients are presented in Table 4.

\begin{tabular}{|lc|}
\hline \multicolumn{2}{|l|}{ Table 4. Laboratory characteristics of the patients } \\
\hline Kt/V (min: 1.2$)$ & \multicolumn{1}{l|}{ Median (Min-Max) } \\
WBC $(4000-10.000 / \mathrm{uL})$ & $1.5(0.5-2.9)$ \\
Hemoglobin $(13.5-17 \mathrm{~g} / \mathrm{dl})$ & $10.35(6.1-14.5)$ \\
Plt $(100.000-400.000 / \mathrm{uL})$ & $194.000(48.000-513.000)$ \\
ALT(0-41 U/L) & $12(2-756)$ \\
Albumin $(35-52 \mathrm{gr} / \mathrm{dL})$ & $36.5(2-94)$ \\
Glucose $(74-106 \mathrm{mg} / \mathrm{dL})$ & $103(46-258)$ \\
\hline $\begin{array}{l}\text { Kt/V: dialyzer clerance urea. dialysis time/ volüme of distribution of urea;WBC: White } \\
\text { blood cell; Plt: platelet; ALT: Alanine aminotransferase }\end{array}$ \\
\hline
\end{tabular}

\section{DISCUSSION}

It is estimated that worldwide at least 350 million people are chronically infected with HBV, 170 million with HCV and 38 million with HIV, and these infections still cause significant public health problemsacross the world $(7,8)$. Blood is one of the most common routes of transmission of these infections. Patients with end-stage renal disease are at risk due to intravenous exposures, frequent use of blood and blood products, and frequent hospitalizations. In addition, susceptibility to infections due to impaired immune system increases, while vaccine responses decrease. Among these patients, deaths due to infections rank number two following cardiovascular diseases (9-11).

As in the world, hemodialysis is the most frequently applied renal replacement therapy (RRT) in patients with end-stage kidney disease in our country $(12,13)$. As of the end of 2019, there are 61,341 patients in the hemodialysis program in Turkey. These patients are followed in 886 centers, $6.21 \%$ of which are hemodialysis units in university hospitals. According to the Joint Report of the Ministry of Health and the Turkish Society of Nephrology, the number of hemodialysis patients continues to increase over the years. According to the 
latest data, $2.57 \%(\mathrm{n}=1574)$ of these patients were positive for HBsAg, 3.14\% $(n=1928)$ for anti-HCV positivity, $0.43 \%(n=263)$ for both HBsAg and anti-HCV positivity, and $0.11 \%(n=67)$ for anti-HIV positivity (13).

In our study, HBsAg positivity was found only in $1 \%$ of our patients. This low rate may be due to several reasons including Hepatitis B vaccine programs' implementation for hemodialysis patients, Hepatitis B vaccine's being added to childhood vaccines since 1998, screening of patients regularly for viral infections in accordance with the guidelines, using separate machines in isolations for HBsAg positive patients, hygiene and infection control rules' being followed by both patients and health professionals, and provision of good in-service training for health workers.

Among studies conducted with hemodialysis patients in Turkey, Sayar et al. (14) did not detect HBsAg positivity in Van province. Similarly, both Temiz et al. (15) and Yüksel et al. (16) did not detect HBsAg positivity in Diyarbakır province. However, HBsAg positivity rate was found as $0.9 \%$ by Asgin et al. (17) in Karabük province, $3.6 \%$ by Evirgen et al. in Hatay province (18), 5.5\% by Çopur Çiçek et al. (4) in Rize province, $5.8 \%$ by Eser Karlıdağ et al. (19) in Elazı̆̆ province, $8.7 \%$ by Sirmatel et al. in Gaziantep province, and $0.7 \%$ by Güvenir et al. (20) in the Turkish Republic of Northern Cyprus. In our neighbors, this rate was found to be $3.2 \%$ for Iraq and $2 \%$ for Iran $(21,22)$. In countries from different continents, the prevalence of $\mathrm{HBV}$ positivity was found as $2.98 \%$ for Botswana, $16.1 \%$ for Pakistan, $0 \%$ for Brazil, 12\% for Kosovo, and $1.03 \%$ for Spain (21-27). As seen, the rates vary from by country and even in different geographical regions of one country.

Turkey is a country with low prevalence of HCV. This may be because intravenous drug use, which is the most important route of transmission in developed countries, is low in our country and blood donors have been tested for $\mathrm{HCV}$ since 1996 (3, 28, 29). Nevertheless, the rate can be higher in hemodialysis patients due to frequent parenteral interventions and lack of a protective vaccine as in Hepatitis B. In our study, $\mathrm{HCV}$ positivity was $3.1 \%$, two of the patients positive for anti-HCV had negative HCV RNA, and one of them became negative after antiviral treatment. In addition, one male patient could not receive antiviral treatment due to his foreign nationality and his HCV RNA value was detectable.

Studies conducted in our country have shown that hemodialysis patients have anti-HCV positivity at rates ranging from $1.2 \%$ to $16 \%(2,4,14-19)$. Among international studies, the prevalence of anti-HCV was determined as $4.3 \%$ by Ibrahim et al. (21) in Iraq, $8.3 \%$ by Roushan et al. (22) in Iran, $43 \%$ by Telaku et al. (24) in
Kosovo, and $43.2 \%$ by Lodhi et al. (26) in Pakistan. Our anti-HCV rate was close to Turkey's average.

Hemodialysis process also carries a significant risk in terms of HIV transmission. HIV transmissions originating from overseas hemodialysis units have been reported in the past years. In 1990, 33 kidney patients were infected with HIV in a dialysis center in Cordoba, Argentina, where same hemodialysis filters were used repeatedly for different patients (30). Similarly, an HIV infection outbreak was reported among 39 patients in two dialysis centers in Egypt in 1993 (31). Although similar incidents are no longer encountered, these outbreaks show how disruptions in infection control measures can cause severe health consequences.

Our study found anti-HIV positivity as $2.1 \%$. Sayar et al. (14), Temiz et al. (15), Yüksel et al. (16), and Eser Karlıdağ et al. (19) found no anti-HIV positivity in their hemodialysis study populations. Güvenir et al. (20) reported anti-HIV positivity for only one patient $(0.7 \%)$. The rate of anti-HIV positivity in our dialysis centeris higher than those reported in other Turkish studies. In the report of the Turkish Society of Nephrology published in 2019, anti-HIV positivity was determined as $0.11 \%$ for hemodialysis patients. Although Turkey is not a country with high HIV prevalence, the rates were high in our study. As we have a machine reserved for HIV-positive patients and a specific clinic to which HIVpositive individuals in our region are referred in need, which probably results in a higher frequency of HIV positive dialysis patients.

Anti-HBs positivity was observed in $59.4 \%(n=57)$ of the patients. The rate was significantly high for patients who have been on dialysis for more than 3 months. Patients in need of renal replacement therapy usually were tested and included in the vaccination program as soon as possible, preferably before starting dialysis. Six patients who were known to have antibodies against Hepatitis B before, were tested negative for Hepatitis B antibodies. Low antibody response and seroconversion may develop in patients with advanced kidney disease and their vaccine responses may be less permanent than healthy individuals. Whether a booster dose is needed for patients with end stage kidney disease should be evaluated regularly with annual anti-HBs titer checks $(32,33)$. It should be kept in mind that Anti-HBs titers may decrease more rapidly in these patients, and a revaccination plan should be recommended for patients without adequate antibody response (Anti-HBs $<10 \mathrm{IU} / \mathrm{ml}$ ) to protect them from the risk of hepatitis $\mathrm{B}$ infection $(32,34)$. A booster dose was administered to these six patients whose antibodies were found to be negative. The patients undergoing dialysis from fistula had high anti-HBs positivity. Before surgical 
procedures, hepatitis $\mathrm{B}, \mathrm{C}$ and HIV status are usually checked, they probably were administered a hepatitis $\mathrm{B}$ vaccine booster dose if needed after an antibody control before the fistula was created.

According to the annual joint reports of the Turkish Society of Nephrology, both HBsAg, anti-HCV and anti-HIV positivity have decreased over the years. Experienced health personnel, regular staff and patient training and high compliance with hygiene rules have a significant contribution to this decline. No additional risk factor that would cause HBsAg, anti-HCV, and antiHIV positivity was encountered in our study. This was attributed to proper observance of infection control measures and careful work of healthcare professionals.

Limitation: Since this was a retrospective study, all patient data could not be reached in our study.Also our dialysis center is based in a tertiarity hospital, which may cause a selection bias and therefore our results may not reflect other dialysis centers, especially centers not affiliated with hospitals.

\section{CONCLUSION}

Hemodialysis patients may be at an increased risk for hepatitis B, hepatitis C and HIV infection than the general population if infection control guidelines are not followed strictly. In addition to complying with these guidelines, both health workers and patients should be trained constantly, patients' virological indicators should be tested, patients should be vaccinated as soon as possible and hepatitis B vaccine should be re-administered to hemodialysis patients without seroconversion or if their antibody responses change.

\section{ETHICAL DECLARATIONS}

Ethics Committee Approval: The study was carried out with the permission of Medeniyet University Göztepe Training and Research Hospital Ethics Committee (Date: 02.09.2020, Decision No: 2020/0551).

Informed Consent: Because the study was designed retrospectively, no written informed consent form was obtained from patients.

Referee Evaluation Process: Externally peer-reviewed.

Conflict of Interest Statement: The author has no conflicts of interest to declare.

Financial Disclosure: The author declared that this study has received no financial support.

Author Contributions: The author declare that they have all participated in the design, execution, and analysis of the paper, and that they have approved the final version.

\section{REFERENCES}

1. Schweitzer A, Horn J, Mikolajczyk RT, Krause G, Ott JJ. Estimations of worldwide prevalence of chronic hepatitis $\mathrm{B}$ virus infection: a systematic review of data published between 1965 and 2013. Lancet 2015; 386: 1546-55.

2. Sirmatel F, Sirmatel Ö, Usalan C, et al. Hemodiyaliz hastalarında viral hepatit B ve C seroprevalansı. İnfeksiyon Derg 2008; 22: 23-8.

3. Cornberg M, Razavi HA, Alberti A, et al. A systematic review of hepatitis $\mathrm{C}$ virus epidemiology in Europe, Canada and Israel. Liver Int 2011; 31: 30-60.

4. Çopur Çiçek A, Şahin İ H, Topaloğlu MK, et al. Rize ilinde hemodiyaliz hastalarında HBsAg, anti-HBs veanti-HCV seroprevalansı. Viral Hepat J 2013; 19: 15-8.

5. HIV-AIDS İstatistik, T.C. Sağlık Bakanlığı, Halk Sağlığı Genel Müdürlüğü Bulaşıcı Hastalıklar ve Erken Uyarı Daire Başkanlığı. https://hsgm.saglik.gov.tr/tr/bulasici-hastaliklar/hiv-aids/hivaids-liste/hiv-aids-istatislik.html, Accessed 31 August 2021.

6. Türkiye 2015 Yilı Ulusal Nefroloji, Diyaliz ve Transplantasyon Kayıt Sistemi Raporu. Türkiyede Nefroloji, Diyaliz ve Transplantasyon. T.C. Sağlık Bakanlığı ve Türk Nefroloji. Derneği Ortak Raporu https://www.nefroloji.org.tr/folders/file/2015_ REGISTRY_kontrol_v2.pdf, Accessed 31 August 2021.

7. Parry J. At last a global response to viral hepatitis. Bull World Health Organ 2010; 88: 801-2.

8. HIV/AIDS, World Health Organization.https://www.who.int/ news-room/fact-sheets/detail/hiv-aids, Accessed 31 August 2021.

9. Betjes MG. Immune cell dysfunction and inflammation in endstage renal disease. Nat Rev Nephrol 2013; 9: 255-65.

10. Kato S, Chmielewski M, Honda H, et al. Aspects of immune dysfunction in end-stage renal disease. Clin J Am SocNephrol 2008; 3: 1526-33.

11.Sarnak MJ, Jaber BL. Mortality caused by sepsis in patients with end-stage renal disease compared with the general population. Kidney Int 2000; 58: 1758-64.

12.Saran R, Robinson B, Abbott KC, et al. US Renal Data System 2019 Annual Data Report: Epidemiology of Kidney Disease in the United States. Am J Kidney Dis 2020; 7: A6-A7.

13. Türkiye 2019 Yılı Ulusal Nefroloji, Diyaliz ve Transplantasyon Kayıt Sistemi Raporu. Türkiye'de Nefroloji, Diyaliz ve Transplantasyon. T.C. Sağlık Bakanlığı ve Türk Nefroloji. Derneği Ortak Raporu http://www.nefroloji.org.tr/folders/file/registry_2019.pdfISBN 978 - 605 - 62465 - 0 - 0 Ankara - 2020, Accessed 31 August 2021.

14. Sayar M, Bulut D, Haykır Solay A. Van Eğitim ve Araştırma Hastanesi'ndeki hemodiyaliz hastalarında $\mathrm{HBV}, \mathrm{HCV}$ ve $\mathrm{HIV}$ serolojik İndikatörleri. Ankara Eğitim ve Araştırma Hastanesi Tıp Derg 2019; 52: 153-7.

15. Temiz H, Kaya Ş, Berekatoğlu N, Temiz S, Danış R. Hemodiyaliz hastalarinda HBV, HCV ve HIV seroprevalansı ve hepatit B aşılaması ile oluşan antikor cevabının değerlendirilmesi. Viral Hepat J 2013; 19: 140-3.

16. Yüksel E, Kaya Ş, Günay E, Araç E. Seroprevalence of HBV, HCV and HIV in hemodialysis patients. Klimik Derg 2019; 32: 165-7.

17. Asgin N, Satilmis S. Evaluation of hepatitis B virus and Hepatitis C virusfrequency in hemodialysis patients. Ann Med Res 2019; 26: 3007-11.

18. Evirgen Ö, Önlen Y, Köksaldı Motor V, Mahsereci E, İnci M, Şahin Ş. Hatay ili hemodiyaliz hastalarında HBV, HCV seroprevalansı ve hepatit B aşılaması ile oluşan antikor cevabının değerlendirilmesi. Viral Hepatit J 2010; 16: 57-63.

19.Eser Karlıdağ G, Küçüksu M, Demir M. HBsAg, anti-HBs, AntiHCV and HIV seroprevalence in hemodialysis patients in Elazığ province. Viral Hepat J 2018; 24: 53-56.

20.Güvenir M, Guler E, Oygar D, Behlul A, Suer K. Evaluating the prevalence of $\mathrm{HBV}, \mathrm{HCV}$, and HIV in hemodialysis patients in North Cyprus. Hepat Mon 2019; 19: e84699. 
21.M.R. Ibrahim N, Sidiq Mohammed Saleem Z, R Hussein N. The Prevalence of HIV, HCV, and HBV among hemodialysis patients attending Duhok Hemodialysis Center. Int J Infect 2018; 5: e63246.

22.Hasanjani Roushan MR, Farokhtabar S, Bayani M, Siadati S. Epidemiological aspects of hepatitis B and C and human immunodeficiency viruses among hemodialysis patients in Mazandaran province, Iran. Nephrourol Mon 2016; 8: e37878.

23. Mahupe P, Molefe-Baikai OJ, Saleshando G, Rwegerera GM. Prevalence and risk factors for hepatitis $b$ and $c$ among end-stage renal disease patients on hemodialysis in Gaborone, Botswana. Niger J ClinPract 2021; 24: 81-8.

24.Lodhi A, Sajjad A, Mehmood K, et al. Profile and predictors of hepatitis and HIV infection in patients on hemodialysis of Quetta, Pakistan. Drug Discoveries \& Therapeutics 2019; 13: 274-9.

25. Guimarães MNC, Facincani T, Santos SSD. Hepatitis B status in hemodialysis patients. ArqGastroenterol 2017; 54: 356-8.

26. Telaku S, Fejza H, Elezi Y, Bicaj T. Hepatitis B and C in dialysis units in Kosova. Virol J 2009; 6: 72.

27. García Agudo R, Aoufi Rabih S, Barril Cuadrado G, et al. Spanish multicentre PIBHE study: prevalence and immunization of chronic hepatitis B in haemodialysis patients in Spain. Nefrologia 2016; 36: 126-32.

28. Shepard CW, Finelli L, Alter MJ. Global epidemiology of hepatitis C virus infection. Lancet Infect Dis 2005; 5: 558-67.

29. Tozun N, Ozdogan O, Cakaloglu Y, et al. Seroprevalence of hepatitis $\mathrm{B}$ and $\mathrm{C}$ virus infections and risk factors in Turkey: a fieldwork TURHEP study. Clin Microbiol Infect 2015; 21: 1020-6.

30. Dyer E. Argentinian doctors accused of spreading AIDS. BMJ. 1993; 307: 584

31.El Sayed NM, Gomatos PJ, Beck-Sagué CM, et al. Epidemic transmission of human immunodeficiency virus in renal dialysis centers in Egypt. J Infect Dis 2000; 181: 91-7.

32. Krueger KM, Ison MG, Ghossein C. Practical Guide to Vaccination in all stages of $\mathrm{CKD}$, including patients treated by dialysis or kidney transplantation. Am J Kidney Dis 2020; 75: 417-25.

33. Kausz A, Pahari D. The value of vaccination in chronic kidney disease. Semin Dial 2004; 17: 9-11.

34. Lewis-Ximenez LL, Oliveira JM, Mercadante LA, et al. Serological and vaccination profile of hemodialysis patients during an outbreak of hepatitis B virus infection. Nephron 2001; 87: 19-26. 